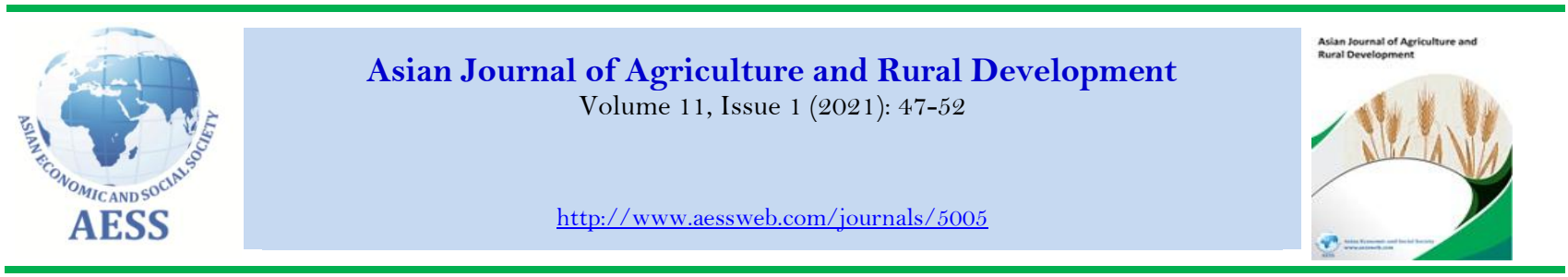

\title{
PERFORMANCE OF AGRICULTURAL EXPORT PRODUCTS ON ECONOMIC GROWTH IN NIGERIA
}

\section{iD Oyetoun Dunmola Amao ${ }^{a}$ \\ iD Michael Akwasi Antwi ${ }^{\text {b }}$ \\ Oluwaseun Samuel \\ Oduniyic \\ (iD) Timothy Olukunle Oni ${ }^{\mathrm{d}}$ \\ Theresa Tendai Rubhara}

\begin{tabular}{l}
\hline Article History \\
\hline Received: 23 June 2020 \\
Revised: 21 December 2020 \\
Accepted: 6 January 2021 \\
Published: 25 January 2021
\end{tabular}

\section{Keywords}

Agricultural export

Diversification

Generalized method of moments (GMM) model

Nigerian economy

Gross domestic product (GDP)

Economic development

Government policies

Nigeria.

\begin{abstract}
${ }^{a}$ National Bioresources Development Agency, Bioresources Development Centre, Nigeria. Malete, Kwara State, Nigeria.

${ }^{b,}$ Department of Agriculture and Animal Health, University of South Africa, South Africa. 'National Institute of Social and Economic Research, Ibadan, Oyo State Nigeria.

${ }^{d}$ University of South Africa, South Africa.
\end{abstract}

هeodunios@unisa.ac.za (Correspondingauthor)

Contribution/Originality: This study is one of very few to have investigated the performance of the agricultural sector on economic growth for a country such as Nigeria whose economy is not agriculture based. The study provides evidence based on reliable secondary data, whereas most previous studies used cross-sectional primary data.

DOI: $10.18488 /$ journal.ajard.2021.111.47.52

$\operatorname{ISSN}(\mathrm{P}):$ 2304-1455/ ISSN(E): 2224-4433

How to cite: Oyetoun Dunmola Amao --- Michael Akwasi Antwi --- Oluwaseun Samuel Oduniyi --- Timothy Olukunle Oni --- Theresa Tendai Rubhara (2021). Performance of Agricultural Export Products on Economic Growth in Nigeria. Asian Journal of Agriculture and Rural Development, 11(1), 47-52. 10.18488/journal.ajard.2021.111.47.52 


\section{INTRODUCTION}

Farming has a powerful influence on any nation; a nation devoid of sustainable agricultural practices will always rely on other countries to acquire food for its inhabitants. The probable involvement of agriculture in enlarging a country's economy has been a major issue for development economists. Several researchers have proved that the development of the entire country depends on the progress of the farming sector, which perhaps will be a conduit for rural earnings with the stipulation of property in support of conversion keen on a developed financial system (Agboola, Oyekale, \& Oduniyi, 2017; Awokuse, 2009; Oduniyi, 2018). Oji-Okoro (2011) assumed that farming provides the trade and industry sector with expansion and enlargement through five inter-segmental connections. Those segments are connected through (i) provision of excess labour to corporations in the industrialized segments; (ii) foodstuffs for indigenous utilization; (iii) supply fromf the marketplace in favour of industrialized yield; (iv) provision of local reserves and industrialized venture; and (v) provision of international trade through farm produce exportation income to sponsor importation of mid- and principal produce.

The importance of exportation to global businesses with trade and industry intensification is a mechanism indispensable for the improvement of a financial system, and hence the importance of exportation to the global business cannot be overemphasized (Timmer, 2002). The development of the export sector will result in employment generation and will thus enhance living standards. Ever-increasing export income assists in reducing the strain on the stability of imbursement instability. Usman and Salami (2008) emphasized that exportation assists in growing the stature of collective trade and industry performance via its multifaceted effects on the level of nationwide earnings. Export is a determining factor in the development of both mature and maturing economies. The exports of maturing nations are composed chiefly of natural assets, but those of matured nations are largely composed of capital supplies.

The main strategic drive behind the export-led enlargement concept is that non-natural resources depend on goods. Kaldor (1970) emphasized that growing exports is the focus for development, the reason being that exportation generates encouraging externalities through the use of a super-competent institutional organization with manufacturing ability (Anthony, Chukwudi, \& Wilfred, 2015). An underdeveloped economy can be transformed into a flourishing economy by an efficient export force (Abogan, Akinola, \& Baruwa, 2014). Revenue earned through the export of agricultural goods will assist in escalating demand in the financial system (Abdlazizi, Naseem, \& Slesman, 2018). Movement in addition to models of operations within the non-oil segment of Nigeria showed that, regardless of diverse approaches, plans, and improved activities, the offerings from subsegments of non-oil segments remained very poor (Abogan et al., 2014). Low productivity characterized Nigeria's agricultural sector, which represents the core of the country's economy. This is the result of very small farms, the use of unsophisticated and old-fashioned farming methods, poor access to credit services, poor manufacturing technology, and deficient inputs for farmers, due to shortfall in the availability of production factors (Abogan et al., 2014).

Vigorous and well-constructed exportation is a pointer to the competitiveness of both goods and services, and a nation's comparative advantage is used in measuring the magnitude of manufacturing entities within the economy (Onodugo, Ikpe, \& Anowor, 2013). Produce is likely to be exported if local requirements are met,; moreover, superfluous produce subsists in marketable magnitude. Many studies have investigated the relationship between non-oil exports and trade and industrial development. Okoh (2004) noted that international corporations had encouraging, but not noteworthy, associations with illuminaton of the performance of non-oil sales abroad in the long run. Furthermore, between 1950 and 1960, agriculture was responsible for 60-70\% of the entire exports of Nigeria (Daramola, Ehui, Ukeje, \& McIntire, 2007). Nigeria was a chief exporter of cocoa, cotton, palm oil, palm kernel, groundnut, and rubber, with a regular yearly growth rate of $3-4 \%$ attained for agricultural and food crops (Daramola et al., 2007). Agricultural export taxes were the mainstay of government revenues, and agriculture was to some extent the foundation for the current fiscal balance (Daramola et al., 2007). The average yearly growth rate of agricultural exports had decreased by $17 \%$ by the mid-1970s to mid-1980s. By 1996, agriculture accounted for barely $2 \%$ of all exports. According to Daramola et al. (2007), agricultural exports have reduced significantly, the severe reduction in agricultural exports being an indication of the weak competitiveness of Nigerian agriculture. Therefore, Nigeria turns is now a net importer of agricultural produce rather than a net exporter.

In addition, there was no appreciable increase in Nigeria's agricultural export market because the majority still went to European Union countries - in raw form, devoid of value addition (Daramola et al., 2007). The oil price crisis of 1973-1974, and in 1979, was the chief reason for the decline in agricultural exports, which culminated in the inflow of foreign trade with the abandonment of agricultural segments due to "Dutch disease" (Sachs, Warner, \& Andrew, 2001). As a result, Nigeria started to import a number of agricultural goods that it also officially exported, as well as additional food crops in which it had previously been self-reliant. Over 96.6\% of Nigeria's exports were lost at nominal terms between 1970 and 1982 (Abdlazizi et al., 2018). The production of domestic foodstuffs also declined significantly, resulting in imports reaching a peak of around \$4 billion in 1982 (Abdlazizi et al., 2018). An enormous increase in importation was funded through oil turnover, which enhanced constructive financial credit balance in the years 1979 and 1980 (Daramola et al., 2007).

By 1986 the situation had reached crisis point, showing that the policy of industrialization during import exchanges was ineffective. This approach levied relatively higher import duty on finished products as compared to raw materials and semi-finished products, in an effort to promote local manufacturing industries (Sachs et al., 2001). Based on this information, the present research investigated the accomplishments of agricultural export products in the economic development of Nigeria. Have government policies regarding the agricultural sector improved the economy? What are the factors that influence government contributions in the agricultural sector? 


\section{MATERIALS AND METHODS}

The study employed an uncomplicated production function: $\mathrm{Y}=\mathrm{AK}$ (Y represents productivity, A represents technical advancement while $\mathrm{K}$ represents assets and adopts non-diminishing returns towards assets). This research adopted the Solow-Swan production function, a financial model used for long-term financial development fixed in a structure of neoclassical economics - like a foundation towards improving financial development representation in support of the present research. The representation aims to clarify long-standing financial expansion by considering asset accretion, workforce, and technical development, owing to its predominantly smart mathematical features. SolowSwan proved to be a suitable preliminary stage regarding several expansions:

$$
\mathrm{Y}=\mathrm{f}(\mathrm{L}, \mathrm{K})
$$

The manufacturing function should be extended by the addition of agricultural exports:

$$
Y t=\mathrm{f}\left(\mathrm{LEB} t, \text { DCFt, POPGt, AGRIC_E } \mathrm{E}_{\mathrm{t}}, \mu\right)
$$

The representation can be altered by inclusion of both exchange rate and foreign direct investment as regulator variables:

$$
G D P t=\mathrm{f}(\mathrm{LEB} t, \text { OER } t, \text { FDI } t, \text { DCF } t, \text { POPGt, AGRIC_E } t, \mu)
$$

where GDPt is the yearly gross domestic product.

LEB $t$ denotes life expectancy at birth.

OER $t$ represents the official exchange rate.

FDI $t$ denotes foreign direct investment.

$\mathrm{DCF} t$ is domestic credit provided by a financial institution.

POPG $t$ is population growth.

AGRIC_E $t$ is agricultural export while $\mu$ is the error term.

Lastly, according to Equations 2 and 3, Equation 4 is a derivative that captures the natural logarithm of the two sides of Equation 3 by omitting any alteration of units in capacities towards parameters, and towards diminishing breach amid self-determining parameters along with reliant parameters. Growth accounting is employed to ascertain the basis for financial development. According to the neo-classical expansion concept that estimates cumulative productivity $\left(\mathrm{Y}_{\mathrm{t}}\right)$ at time $\mathrm{Y}$, a function of capital $\left(\mathrm{K}_{\mathrm{t}}\right)$, labour $\left(\mathrm{L}_{\mathrm{t}}\right)$ and the entire factor of production $(\mathrm{At})$ assuming that $0<\alpha<1$ and $\mu>0$ :

$$
Y_{t}=A_{t}^{\mu} f\left(K_{t}^{\alpha}, L_{t}^{1-\alpha}\right)
$$

Although the focus of the study is value addition through the farming segment in regard to national financial growth along with value addition via the agrarian subsector towards agriculture, aggregate output $\left(\mathrm{Y}_{\mathrm{t}}\right)$ was conceptualized in the entirety of each segment of the nationwide financial system accomplishment. The cumulative output of the economy $\left(\mathrm{Y}_{\mathrm{t}}\right)$ expresses sectorial productivities and each sectorial production is presumed to be the sum of the yields of its subsectors. The aggregate and sectorial outputs are specified thus:

$$
\begin{aligned}
Y_{t} & =\sum_{t}^{T} Y_{i t} \\
Y_{i t} & =\sum_{t}^{T} Y_{i j t}
\end{aligned}
$$

where $\left(Y_{t}\right)=$ cumulative productivity in a financial system at time $\mathrm{t}$.

$\left(\mathrm{Y}_{\mathrm{it}}\right)=$ segment productivity at time $\mathrm{t}$.

$\left(\mathrm{Y}_{\mathrm{ijt}}\right)=$ subsegment productivity $\mathrm{j}$ at time $\mathrm{t}$.

Assuming that segment and subsegment outputs combine progressively towards the cumulative productivity. The possibility of progression for each respective segment in the financial system affects expansion in cumulative productivity. Similarly, subsectorial growth can be the basis of sectorial growth. Therefore, growth in cumulative productivity and growth in sectorial yield are identified as the first derivative of Equations 5 and 6 :

$\frac{\partial Y_{t}}{Y_{t}}=\sum_{t}^{T} \frac{\partial Y_{i t}}{Y_{i t}}$

$\frac{\partial Y_{i t}}{Y_{i t}}=\sum_{t}^{T} \frac{\partial Y_{i j t}}{Y_{i j t}}$

where $\frac{\partial Y_{t}}{Y_{t}}$ stands for the growth in cumulative productivity of the economy at period $t$.

$\frac{\partial Y_{i t}}{Y_{i t}}$ represents growth in the productivity of sector i at period $\mathrm{t}$.

$\frac{\partial Y_{i j t}}{Y_{i j t}}$ denotes productivity sub-segment $\mathrm{j}$ at time $\mathrm{t}$.

Growth over all segments and subsegments is expected to create progressive achievement of cumulative productivity expansion. Growth in aggregate and sectorial output is generally stated thus:

$\frac{\partial Y_{t}}{Y_{t}}=\sum_{t}^{T} \frac{Y_{i t}}{Y_{t}} \cdot \frac{\partial Y_{i t}}{Y_{i t}}$

$\frac{\partial Y_{i t}}{Y_{i t}}=\sum_{t}^{T} \frac{Y_{i j t}}{Y_{i t}} \cdot \frac{\partial Y_{i j t}}{Y_{i j t}}$

where $\frac{Y_{i t}}{Y_{t}}$ represents the portion of the productivity of sector $\mathrm{i}$ in the cumulative productivity in period $\mathrm{t}$.

$\frac{Y_{i j t}}{Y_{i t}}$ represents the productivity of subsector $\mathrm{j}$ portion in sectorial productivity at time $\mathrm{t}$. Expansion of segments and subsegments was evaluated and is expected to enhance the development of cumulative productivity. 
The Nigerian economic sectors, according to the definition of CBN and NBS, are agricultural exports, official exchange rate, foreign direct investment, life expectancy at birth, domestic credits obtainable from financial institutions, and population growth. The subsegments in the agrarian segment are grouped as food and live animals, beverages and tobacco, crude materials, and inedible produce except fats and animal and vegetable oils. Value additions to both segments and subsegments are included and estimated:

gdpgrow = wagric_egrow + wlebgrow + woergrow + wpopggrow + wfdigrow + wdefgrow $+\mathrm{e}_{\mathrm{i}}$

agrgrow $=$ wfla_egrow + wbetogrow + wcmine_egrow + wavof_egrow $+\mathrm{e}_{\mathrm{i}}$

gdpgrow $=$ growth in GDP in time $t$.

wagric_egrow $=$ weighed growth rate of agricultural export in period $t$.

wlebgrow $=$ weighed growth rate of life expectancy at birth in period $t$.

woergrow $=$ weighed growth rate of official exchange rate in time $t$.

wpopggrow $=$ weighed growth rate of population growth in time $t$.

wfdigrow $=$ weighed growth rate of foreign direct investment in period $t$.

wdcfgrow $=$ weighed growth in domestic credit available from a financial institution in period $t$.

wflaegrow $=$ weighed growth rate of food and live animals in period $t$.

wbetogrow $=$ weighed growth rate of beverages and tobacco in period $t$.

wcmineegrow $=$ weighed growth rate of crude materials, inedible except fats, in period $\mathrm{t}$.

wafovegrow $=$ weighed growth rate of animal and vegetable oils and fats in period $t$.

\section{RESULTS AND DISCUSSION}

The data were analyzed using the general method of moment (GMM) to ascertain the performance of agricultural exportation products on Nigeria's trade and industry development. Information for the present study was collected from the Central Bank of Nigeria (CBN annual reports and statistical bulletin), the Nigerian Bureau of Statistics (NBS), and the World Bank. This ensured the validity and the reliability of the data employed. The performance of agrarian exportation product on trade and industry development was analyzed using GMM, and the statistical results are presented in Table 1. Analysis was conducted on the effects of agricultural export products, and subsectors thereof, on total output, and of agricultural export products and subsectors on agricultural output. It is evident from the analysis that agricultural output cannot solely comprise GDP: one way or another, the agricultural sector also added value to all other sectors contributing to GDP, and vice versa. This study takes into consideration the impact of agricultural export products on other sectors when looking at how they help to grow the Nigerian economy. This research work is not unfamiliar with the existence of endogeneity in the explanatory variables that contribute to GDP, and therefore the research adopted the use of GMM to study endogeneity that might occur within parameters such as foreign direct investment (FDI), the official exchange rate (OER), life expectancy at birth (LEB), domestic credit provided by the financial sector (DCF), population growth (POPG), and agricultural export products (AGRIC_E), which comprise food and live animals (FLA_E), beverages and tobacco (BETO), crude materials, inedible except fats (CMINE), and animal and vegetable oils and fats - referred to as agricultural export products.

Table 1 shows the effect of the total agricultural product for exportation on total output (GDP). It also reveals the performance of agricultural export subsector products on total output. In Table 1, all other sectors show a negative but significant impact on total output (GDP_O) except LEB $(\mathrm{t}=14.72$, coef $=1.079$ at $p<0.01)$ that is positive and significant regarding GDP_O. The total agricultural export product $(\mathrm{t}=-1.34$, coef $=-0.1321$ at $p>0.1)$ is negative and insignificant regarding GDP_O. Looking at the subsector impact on agricultural export product under FLA_E, all other factors except LEB are negative but significant $(\mathrm{t}=13.45$, coef $=1.0698$ at $p<0.01)$, which is positive and significant. FLA_E itself is negative and significant $(p<0.1)$. The impact of BETO is negative $(\mathrm{t}=-2.72$, coef $=-$ $0.1195)$ but significant $(p<0.01)$, while other factors are also negative but significant. Looking at the impact of CMINE_E, CMINE_E itself is negative and insignificant $(\mathrm{t}=-1.45$, coef $=-0.1141$ at $p>0.1)$, LEB is positively significant while all the other factors are negative but notably effective. The effect of AVOF_E is progressive but negligible $(\mathrm{t}=0.19$, coef $=0.0126$ at $p>0.1)$. Consequently, the $F$-statistic for Table 1 shows that all explanatory variables, including the agricultural export subsector, are sufficient to explain the dependent variables while $R^{2}$ shows the reliability of explanatory variables not $<90 \%$, i.e., they are significant at $1 \%, 5 \%$, and $10 \%$.

\subsection{Presentation and Interpretation of Results}

The study reveals that agricultural export products have an a weak influence on expansion of the national financial system. Reduced yields consequently resulted in poor economic performance characterized by food insecurity, insufficient provision of raw materials, raised levels of joblessness, skyrocketing cost of living, inaccessibility of farmers to finance, unwarranted borrowing, exchange rate devaluation, and import reliance. A downward trend was observed in the production of agricultural products, exportation of agricultural products, and proportion of agricultural production in national GDP over the period of global economic meltdown (Loto, 2011). Throughout the period of global economic meltdown, both the contribution of the agricultural sector to GDP and the exportation of farm product indicated minimal improvement. Non-oil exportation showed a negligible influence on expansion of the Nigerian financial system (Onodugo et al., 2013). Adesuoji and Sotubo (2013) also observed that non-oil exportation has minimal value in the development of the domestic economy. Reduced viability of agricultural product exportation in enhancing national economic growth is a pointer to the reduced productivity of agricultural subsectors, which is expected to culminate in poor overall agricultural export levels. 
Asian Journal of Agriculture and Rural Development, 11(1)2021: 47-52

\begin{tabular}{|c|c|c|c|c|c|c|c|c|c|c|}
\hline \multirow[t]{2}{*}{ Variable } & \multicolumn{2}{|c|}{ LNGDP_O } & \multicolumn{2}{|c|}{ LNGDP_O } & \multicolumn{2}{|c|}{ LNGDP_O } & \multicolumn{2}{|c|}{ LNGDP_O } & \multicolumn{2}{|c|}{ LNGDP_O } \\
\hline & Coef & T-test & Coef & T-test & Coef & T-test & Coef & T-test & Coef & T-test \\
\hline FDI & -0.3774 & $-3.41 * * *$ & -0.3764 & $-3.47 * * *$ & -0.3424 & $-2.80^{* * * *}$ & -0.3638 & $-3.16^{* * * *}$ & -0.3145 & -2.17 ** \\
\hline OER & -0.0091 & $-2.87 * * *$ & -0.0094 & $-2.84 * * *$ & -0.0126 & $-3.34 * * *$ & -0.0086 & $-2.73 * * *$ & -0.0077 & $-1.92^{*}$ \\
\hline LEB & 1.0790 & $14.72 * * *$ & 1.0698 & $13.45^{* * * *}$ & 1.2416 & $14.61^{* * * *}$ & 1.0807 & $14.82^{* * * *}$ & 1.0156 & $10.55^{* * * *}$ \\
\hline DCF & -0.0300 & $-3.04 * * * *$ & -0.0273 & $-2.60 * * *$ & -0.0235 & $-2.06 * *$ & -0.0341 & $-3.35 * * *$ & -0.0256 & $-2.08 * *$ \\
\hline POPG & -2.7534 & $-4.65^{* * * *}$ & -2.6667 & $-4.37 * * *$ & -3.6638 & $-6.25^{* * * *}$ & -2.8921 & $-5.08 * * *$ & -2.8429 & $-4.38 * * *$ \\
\hline LNAGRIC_E & -0.1321 & -1.34 & & & & & & & & \\
\hline LNFLA_E & & & -0.1310 & $-1.84^{*}$ & & & & & & \\
\hline LNBETO & & & & & -0.1195 & $-2.72^{* * *}$ & & & & \\
\hline LNCMINE_E & & & & & & & -0.1141 & -1.45 & & \\
\hline LNAVOF_E & & & & & & & & & 0.0126 & 0.19 \\
\hline CONSTANT & -26.5136 & -9.63 & -26.4517 & -9.04 & -32.6996 & -11.01 & -26.5811 & -9.91 & -25.4614 & -6.80 \\
\hline $\operatorname{Adj} R^{2}$ & \multicolumn{2}{|c|}{0.903} & \multicolumn{2}{|c|}{0.903} & \multicolumn{2}{|c|}{0.910} & \multicolumn{2}{|c|}{0.902} & \multicolumn{2}{|c|}{0.896} \\
\hline$F$-statistic & \multicolumn{2}{|c|}{$52.38(0.000)$} & \multicolumn{2}{|c|}{$52.53(0.000)$} & \multicolumn{2}{|c|}{$53.64(0.000)$} & \multicolumn{2}{|c|}{$51.66(0.000)$} & \multicolumn{2}{|c|}{$48.86(0.000)$} \\
\hline Number of Obs. & \multicolumn{2}{|c|}{34} & \multicolumn{2}{|c|}{34} & \multicolumn{2}{|c|}{32} & \multicolumn{2}{|c|}{34} & \multicolumn{2}{|c|}{34} \\
\hline
\end{tabular}




\section{CONCLUSION AND RECOMMENDATIONS}

The GMM test was employed, and the outcome revealed that total agricultural product exportation makes a worryingly minute contribution to Nigeria's financial system. We also investigated subsectors of farming export products, since these contribute to the agricultural export sector. The results investigated the subsectors used for this study - food and live animals, beverages and tobacco, and crude materials inedible except fats. Of of these subsectors, both food and live animals and beverages and tobacco were significant, at 10 and $1 \%$, respectively. However, the significance of these two subsectors had a negative influence on expansion of the national financial system. Crude materials inedible except fats had a negative and insignificant influence on financial system expansion, while animal and vegetable oils and fats had a positive but not marked influence. The negative relationship of agricultural export products to economic growth began when petroleum was found - more importantly, rapid expansion of the crude oil industry resulted in abandonment of the agrarian sector, which turned Nigeria's economy into an oil-dependent economy. All other factors, including credit, exchange rate, investment, and even the efforts of those who ought to boost the production and exportation of products from the agricultural sector, were unable to grow the nation's economy.

This study recommends that both the government and private sector should attempt to intensify, diversify, and encourage the production of local agricultural commodities to increase that sector's contribution to the economy, and thus eventually to stimulate national economic growth. The following policies should be considered:

- The government should encourage school leavers to enter the agricultural sector and should make farming attractive to them through youth agricultural empowerment, especially in the production of cocoa, textiles, wood products, cork, and coffee.

- Both the government and the private sector should address the need to add value to agricultural products through agro-processing, to maximize the value of exports.

Funding: This study received no specific financial support.

Competing Interests: The authors declare that they have no competing interests.

Contributors/Acknowledgement: All authors contributed equally to the conception and design of the study.

Views and opinions expressed in this study are those of the authors views; the Asian Journal of Agriculture and Rural Development shall not be responsible or answerable for any loss, damage, or liability, etc. caused in relation to/arising out of the use of the content.

\section{REFERENCES}

Abdlazizi, R. A., Naseem, N. A. M., \& Slesman, L. (2018). Dutch disease effect of oil price on agriculture sector: Evidence from panel cointegration of oil exporting countries. International Journal of Energy Economics and Policy, 8(5), 241-250.

Abogan, O., Akinola, E., \& Baruwa, O. (2014). Non-oil export and economic growth in Nigeria. Journal of Research in Economics and International Finance, 3(1), 1-11.

Adesuoji, A. A., \& Sotubo, O. D. (2013). Non-oil exports in the economic growth of Nigeria: A study of agricultural and mineral resources. Journal of Educational and Social Research, 3(2), 403-418.Available at: 10.5901/jesr.2013.v3n2p403.

Agboola, P. T., Oyekale, S., \& Oduniyi, O. S. (2017). Assessment of welfare shocks and food insecurity in ephraim mogale and greater Tubatse Municipality of Sekhukhune Districts, Limpopo Province, South Africa. IOSR Journal of Agriculture and Veterinary Science, 1O(4), 23-32.Available at: https://doi.org/10.9790/2380-1004022332.

Anthony, I., Chukwudi, E. E., \& Wilfred, I. U. (2015). Impact of non-oil sector on economic growth: A managerial economic perspective. Problems and Perspectives in Management, 13(2), 170-182.

Awokuse, T. O. (2009). Does agriculture really matter for economic growth in developing countries? Paper presented at the Selected Paper Prepared for Presentation at the American Agricultural Economics Association.

Daramola, A., Ehui, S., Ukeje, E., \& McIntire, J. (2007). Agricultural export potential. In Collier P. and C. Pattillo (Eds.), Economic Policy Options for a Prosperous Nigeria. London: Palgrave Macmillan.

Kaldor, N. (1970). The case for regional policies. Scottish Journal of Political Economy, 17(3), 337-348.

Loto, M. (2011). The impact of economic downturn on the performance of agricultural export in the Nigerian economy: A quarterly empirical analysis. Journal of Emerging trends in Economics and Management Sciences, 2(6), 504-510.

Oduniyi, O. S. (2018). Implication of climate change on livelihood and adaptation of small and emerging maize farmers in the North West Province of South Africa. PhD Thesis, University of South Africa.

Oji-Okoro, I. (2011). Analysis of the contribution of agricultural sector on the Nigerian economic development. World Review of Business Research, 1(1), 191-200.

Okoh, R. (2004). Global integration and the growth of Nigeria's non-oil exports. Paper presented at the African Conference, 21-22 March at Oxford, UK

Onodugo, V., Ikpe, M., \& Anowor, O. F. (2013). Non-oil export and economic growth in Nigeria: A time series econometric model. International Journal of Business Management and Research, 3(2), 115124.

Sachs, J., Warner, D., \& Andrew, M. (2001). The cause of natural resources. European Economic Revierw, 45(4-6), 827-838.

Timmer, C. (2002). Agriculture and economic development. In: Gardener, B.L. and Rausser, G.C. (Eds.), Handbook of Agricultural Economics (1st ed., Vol. 29, pp. 1487-1546). London: Elsevier.

Usman, O., \& Salami, A. (2008). The contribution of Nigerian export-import (NEXIM) bank towards export (non-oil) growth in Nigeria (1990-2005). International Business Management, 2(3), 85-90. 